\title{
PENGARUH MODEL QUANTUM LEARNING TERHADAP KETERAMPILAN MENULIS PUISI SISWA KELAS X AKUNTANSI SMK NEGERI 2 KOTA JAMBI
}

\author{
Abdoel Gafar', Agustina Aritonang ${ }^{2}$ \\ Program Studi Pendidikan Bahasa dan Sastra Indonesia, \\ Fakultas Keguruan dan Ilmu Pendidikan, Universitas Batanghari, \\ Jambi \\ gafar3r@yahoo.co.id \\ agustinajha1@gmail.com
}

\begin{abstract}
This research aims to describe the impact of of quantum learning model towards students ability in writing poetry at class $X$ of accounting major SMK Negeri 2 Jambi City school year 2018/2019. The design of this research uses quasi experiment with a quantitative approach. Sampling was carried out using the purposive sampling technique of the $X$ grade students of SMK Negeri 2 Jambi City. It is obtained that class $X$ of accounting 2 as the experimental class and class $X$ of accounting 3 as the control class. The research results show that the average score of the experimental is 80.42 and the average score of control class is 74. After testing the normality test, the experimental class sig score is $0.170>0.05$ and the control class sig score is $178>0.05$ (significance level). Thus it can be concluded that the data of the two classes is fall intro category of normal distribution. From the homogeneity test, it is obtained that sig score is $0.462>$ of a significant level ( $\alpha$ $=0.05)$ Thus it can be concluded that both classes have the same or homogeneous variants. Hypothesis testing uses SPSS 20 applications. T test of two independent samples shows that SIG T count 0,043 $<0.05$ then Ho is rejected Ha is received. So, the results of students ability in writing poetry at class $X$ of Accounting at SMK Negeri 2 Jambi city that use quantum learning model is better than the learning outcomes of students who use conventional learning.
\end{abstract}

Keywords: Writing Ability, Poetry, Quantum Learning Model

1 Dosen Program Studi Pendidikan Bahasa dan Sastra Indonesia, Fakultas Keguruan dan Ilmu Pendidikan, Universitas Batanghari, Jambi

${ }^{2}$ Mahasiswa Program Studi Pendidikan Bahasa dan Sastra Indonesia, Fakultas Keguruan dan Ilmu Pendidikan, Universitas Batanghari, Jambi

Pengaruh Model Quantum Learning terhadap Keterampilan Menulis Puisi Siswa Kelas X Akuntansi SMK Negeri 2 Kota Jambi 


\section{PENDAHULUAN}

Pendidikan merupakan upaya terencana dalam kehidupan lingkungan sosial peserta didik yang terarah, sebagai proses pembelajaran yang membentuk dan mengembangkan potensi-potensi yang dimilikinya dan membawa perubahan kebiasaan dan sikap menjadi pribadi yang dewasa dan bertanggung jawab serta memiliki kecerdasaan ilmu pengetahuan. Menurut Gustaviana dan A. Rahima (2018:187) bahasa Indonesia dijadikan salah satu mata pelajaran wajib di sekolah mulai sekolah dasar sampai perguruan tinggi. Mata pelajaran bahasa Indonesia bertujuan untuk mempelajari berbagai ranah keilmuan berbahasa dan juga keterampilan berbahasa. Selain itu, pembelajaran bahasa Indonesia diarahkan untuk meningkatkan kemampuan peserta didik berkomunikasi menggunakan bahasa Indonesia dengan baik dan benar, baik secara lisan maupun tulisan (Puspita, dkk., 2019: 105).

Pembelajaran sebagai proses tindakan dalam mempelajari suatu materi yang berpusat pada peserta didik. Pembelajaran menulis bahasa Indonesia di sekolah didasarkan pada keterampilan menulis. Pembelajaran tersebut terutama digunakan pada sekolah yang menggunakan kurikulum 2013. Keterampilan menulis yang baik akan sangat membantu peserta didik dalam menggali kemampuan dan potensi diri dalam menulis. Rofii dkk. (2019A) "Writing skill is one of four language skills that must be mastered by students (Keterampilan menulis merupakan salah satu dari empat keterampilan berbahasa yang harus dikuasai oleh mahasiswa). Salah satu keterampilan menulis yang diajarkan di sekolah adalah menulis puisi.

\section{Menurut Istiqomah, dkk.} (2017:243) "Puisi adalah salah satu bentuk karya sastra yang banyak disukai kerena disajikan dalam bahasa yang indah dan sifatnya yang imajinatif". Ada pengertian lain bahwa puisi dianggap sebagai rangkaian kata-kata yang menggambarkan perasaan penulis. Keterampilan menulis puisi merupakan salah satu keterampilan menulis yang harus dikuasai oleh peserta didik khususnya di sekolah menengah kejuruan kelas X.

Keterampilan menulis puisi diajarkan di sekolah pada semester genap. materi tentang menulis puisi dengan memerhatikan unsur pembangunnya merupakan aplikasi dari KD (kompetensi dasar) 4.17. Tujuan pembelajaran KD (kompetensi dasar) tersebut agar peserta didik memproduksi puisi, memahami unsur-unsur pembangun puisi. Untuk mengoptimalkan proses pembelajaran maka dibutuhkan model pembelajaran yang sesuai.

Model pembelajaran pada dasarnya merupakan bentuk pembelajaran yang akan digunakan guru saat pembelajaran berlangsung. Penting bagi guru untuk mampu memilih model pembelajaran yang sesuai dengan materi yang diajarkan, sehingga dalam proses pembelajaran siswa tidak merasa bosan, jenuh dan monoton. Penggunaan model pembelajaran yang tepat, membuat proses pembelajaran menjadi efektif. Proses pembelajaran yang efektif tentu akan memberikan hasil yang lebih baik.

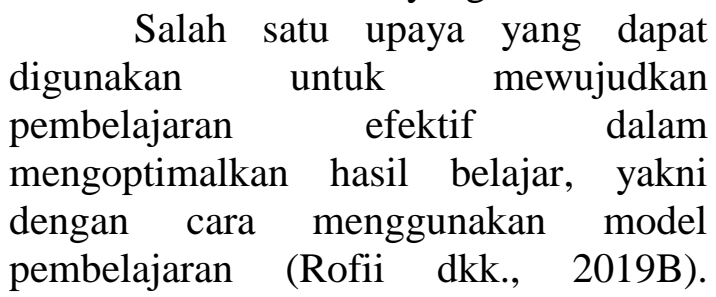


Adapun model pembelajaran yang dapat digunakan adalah quantum learning. Model quantum learning merupakan kiat, petunjuk, strategi, dan seluruh proses belajar yang dapat mempertajam pemahaman dan daya ingat, serta membuat belajar sebagai suatu proses yang menyenangkan bermanfaat.

SMK Negeri 2 Kota Jambi memakai kurikulum 2013. Sehingga menarik untuk diteliti. Berdasarkan pengamatan sementara, serta wawancara dengan guru bahasa Indonesia kelas $\mathrm{X}$ Akuntansi Bapak Oky Akbar, S.Pd, diketahui bahwa model pembelajaran quantum learning belum pernah digunakan guru dalam pembelajaran menulis puisi.

Penelitian ini dilakukan untuk menjawab pertanyaan bagaimanakah pengaruh model quantum learning terhadap keterampilan menulis puisi Siswa Kelas X Akuntansi SMK Negeri 2 Kota Jambi Pada Tahun Ajaran 2018/2019?

\section{Kajian Pustaka}

Pembelajaran suatu kegiatan interaksi tenaga pengajar terhadap peserta didik yang memungkinkan dapat memperoleh pengalaman. Menurut Hamalik (2008:57) "Pembelajaran adalah suatu kombinasi yang tersusun meliputi unsur-unsur manusiawi, material, fasilitas, perlengkapan, dan prosedur yang saling mempengaruhi mencapai tujuan pembelajaran". Menurut Degeng (dalam Uno (2008:2)) "Pembelajaran adalah upaya untuk membelajarkan siswa". Selanjutnya Menurut Daryanto (2009:178) "Pembelajaran adalah suatu interaksi antara instruktur dan pembelajar dalam suatu kegiatan belajar mengajar".

Menurut Hearnacki dan Deporter (dalam Abdurrahman (2016:337))
"Keterampilan adalah alat-alat yang akan dipergunakan dengan konsentrasi dan latihan, anda akan ahli menggunakannya". Hal ini menekankan bahwa keterampilan merupakan alat yang digunakan untuk memiliki konsentrasi dalam menghasilkan suatu karya yang diciptakan. Adapun Menurut Dalman (2014:3) "Menulis merupakan suatu kegiatan komunikasi berupa penyampaian pesan (informasi) secara tertulis kepada pihak lain dengan menggunakan bahasa tulis sebagai alat atau medianya". Rofii dkk. (2019 C) mengatakan Writing is a complex activity requiring extensive and comprehensive knowledge (Menulis adalah kegiatan kompleks yang membutuhkan pengetahuan yang luas dan mendalam). Yanti dkk. (2018) menyatakan Menulis merupakan kegiatan melahirkan pikiran dan perasaan dengan tulisan. Dengan demikian keterampilan menulis merupakan suatu alat yang dipergunakan dengan konsentrasi tinggi yang berupa pesan tertulis dan informasi untuk pembaca dengan menggunakan bahasa tulis yang menjadikan pembaca dapat memahami, mengerti, dan dapat menerapkan pesan yang telah dibacanya.

Selanjutnya menurut Triyanto, dkk. (2013:67) "Menulis merupakan sebuah metode terbaik untuk mengembangkan kemampuan dalam mengungkapkan bahasa". Sejalan dengan pendapat di atas, menurut Lado (dalam Tarigan (1984:21)) "Menulis ialah menurunkan atau melukiskan lambanglambang grafik yang menggambarkan suatu bahasa yang dipahami oleh seseorang, sehingga orang-orang lain dapat membaca lambang-lambang grafik tersebut kalau mereka memahami bahasa dan gambaran grafik itu". 
Tujuan menulis menurut Panuju (dalam Triyanto, dkk. (2013:69-70)) ada lima tujuan utama dalam menulis, antara lain: (1) tujuan menghibur, (2) tujuan menyakinkan dan bedaya bujuk, (3) tujuan penerangan: isi karangan memberi keterangan, (4) tujuan pernyataan diri, dan (5) tujuan kreatif.

Tujuan menulis juga ditinjau dari sudut kepentingan pengarang menurut Dalman (2014:13-14) ada enam tujuan menulis, berikut penjelasan enam tujuan menulis, yaitu: (1) tujuan penugasan, (2) tujuan estetis, (3) tujuan penerangan, (4) tujuan pernyataan diri, dan (5) tujuan kreatif, dan (6) tujuan konsumtif.

Berdasarkan beberapa pendapat yang telah dikemukakan di atas, dapat disimpulkan bahwa tujuan utama pembelajaran keterampilan menulis untuk memberikan informasi dan pemahaman kepada pembaca.

Puisi merupakan jalinan kata-kata yang indah dan memiliki makna yang berasal dari jiwa manusia. Menurut Damayanti (2013:19) "Istilah puisi berasal dari bahasa Yunani kuno 'poieo' atau 'poio' yang berarti saya mencipta. Secara mudahnya, puisi didefenisikan sebagai seni tertulis dimana bahasa digunakan untuk kualitas estetiknya untuk tambahan, atau selain arti semantiknya".

Puisi sebagai karya sastra dapat dikaji dari beberapa aspek. Menurut Istiqomah, dkk. (2017:243) "Puisi adalah salah satu bentuk karya sastra yang banyak disukai karena disajikan dalam bahasa yang indah dan sifatnya yang imajinatif". Selanjutnya menurut Kosasih (2008:31) "Puisi adalah bentuk karya sastra yang tersaji secara monolog, menggunakan kata-kata yang indah dan kaya akan makna”. Hal ini sejalan menurut Wahyuni (2014:12) "Puisi adalah salah satu bentuk karya sastra yang diwujudkan dengan kata-kata indah dan bermakna".

Berdasarkan pendapat tersebut, dapat disimpulkan bahwa puisi merupakan suatu karya tulis yang di dalamnya merupakan sebuah ungkapan atau curahan hati seseorang yang diciptakan berdasarkan suasana kehidupan yang sedang dialami atau fenomena yang terjadi di dunia nyata pencipta puisi tersebut, yang diutarakan melalui tulisan sehingga terangkai sebuah kata-kata yang indah.

Menurut Kosasih (2008:32-38) secara garis besar, unsur-unsur puisi terbagai menjadi dua macam, yakni struktur fisik dan struktur batin. Unsur fisik meliputi hal-hal berikut: (a) diksi (pemilihan kata) adalah kata-kata yang digunakan dalam puisi; (b) pengimajian atau pengimajinasian dapat didefenisikan sebagai kata atau susunan kata yang menimbulkan khayalan atau imajinasi; (c) kata konkret untuk membangkitkan imajinasi pembaca, kata-kata harus diperkonkret atau diperjelas; (d) bahasa figurative (majas) adalah bahasa yang digunakan oleh penyair untuk mengatakan sesuatu dengan cara membandingkan dengan benda atau kata lain; (e) rima/ritma adalah pengulangan bunyi dalam puisi, dengan adanya rima, suatu puisi menjandi indah; (f) tata wajah (tipografi) merupakan perbedaan yang sangat penting antara puisi, prosa, dan drama, larik-larik puisi tidak berbentuk paragraph, tetapi bait.

Unsur-unsur batin pada puisi meliputi hal-hal berikut: (a) tema puisi merupakan gagasan utama penyair dalam puisinya; (b) perasaan dalam puisi merupakan karya sastra yang paling mewakili eksperesi perasaan penyair; (c) nada dan suasana dalam menulis puisi, 
penyair mempunyai sifat tertentu terhadap pembaca; dan (d) amanat dalam puisi merupakan hal yang mendorong penyair untuk menciptakan puisinya.

Berdasarkan uraian di atas, dapat disimpulkan bahwa puisi memiliki unsur fisik dan unsur batin yang harus diperhatikan.

Menurut Markazi (2016) langkahlangkah menulis puisi antara lain: menentukan ide, memasukkan imajinasi, tema yang tepat, buat judul yang menarik, menggunakan kata-kata indah, buat lirik yang menarik, perwajahan atau topografi, gunakan majas.

Teknik penilaian yang digunakan untuk menilai keterampilan menulis puisi adalah teknik penilaian produk (hasil kerja). Penilaian pembelajaran keterampilan menulis puisi menurut Istiqomah, dkk (2017:348), sebagai berikut: (1) orisinalitas ide, yang dimaksud disini tema; (2) kreativitas penggunaan bahasa, yang dimaksud disini diksi seperti makna kias (konotatif), lambang (simbol), dan persamaan bunyi atau rima; (3) keindahan aspek bunyi, yang dimaksud disini pengimajian dan kata konkret, (a) pengimajian adalah kata atau susunan yang dapat mengungkapkan pengalaman sensoris, seperti penglihatan, pendengaran, dan perasaan, (b) kata konkret adalah kata yang memungkinkan munculnya imaji karena dapat ditangkap indera; (4) ketepatan waktu; dan (5) makna puisi.

Paparan pendapat menurut Istiqomah, dkk di atas dijadikan sebagai landasan penilaian hasil belajar dalam melakukan penelitian pembelajaran keterampilan menulis puisi. Setelah mengetahui penilaian tersebut, maka hal yang perlu diperhatikan juga adalah model yang digunakan dalam pembelajaran.

Menurut Trianto (2007:1)

"Model pembelajaran adalah suatu perencanaan atau suatu pola yang digunakan sebagai pedoman dalam merencanakan pembelajaran di kelas atau pembelajaran tutorial". Model pembelajaran merupakan upaya perencanaan untuk mengefektifkan pencapaian tujuan pembelajaran dengan strategi yang akan diterapkan. Adapun kelas eksperimen menggunakan model quantum learning dan kelas kontrol menggunakan model konvensional.

$\begin{array}{ccr}\text { Model } & \text { quantum learning } \\ \text { merupakan } & \text { pembelajaran } & \text { yang }\end{array}$

didasarkan pada konstruktivisme (membangun pengetahuan). Menurut Mulyasa (2014:88) "Quantum learning lebih mengutamakan keterlibatan peserta didik dalam berinteraksi dengan situasi belajarnya, melalui panca inderanya baik melalui pengelihatan, pendengaran, perabaan, penciuman dan pengecapan". Adapun menurut Wahyuni dan Baharuddin (2010:135) sebagai berikut:

Quantum didefinisikan sebagai interaksi yang mengubah energi menjadi cahaya. Semua kehidupan adalah energi. Sedang learning artinya belajar. Belajar bertujuan meraih sebanyak cahaya (interaksi, hubungan, dan inspirasi agar menghasilkan energi cahaya). Dengan demikian, quantum learning adalah cara pengubahan bermacam-macam interaksi, hubungan, dan inspirasi yang ada di dalam dan di sekitar momen belajar.

Selanjutnya menurut Mulyasa (2014:78) "Quantum learning merupakan pendekatan atau strategi belajar yang

Pengaruh Model Quantum Learning terhadap Keterampilan Menulis Puisi Siswa Kelas X Akuntansi SMK Negeri 2 Kota Jambi 
mempertajam pemahaman dan daya ingat, serta membuat belajar sebagai suatu proses yang menyenangkan dan bermanfaat". Jadi, quantum learning merupakan pendekatan belajar yang mempertajam ingatan peserta didik sehingga belajar menyenangkan dan bermanfaat.

$$
\text { Menurut Mulyasa (2014:82) }
$$

"Prinsip quantum learning yang paling utama adalah empati, yakni membawa dunia peserta didik ke dalam dunia guru, dan mengantarkan dunia guru ke dunia peserta didik, dengan peserta didik sebagai subjek belajar". Prinsip dasar yang terdapat dalam quantum learning adalah sebagai berikut, (1) bawalah dunia mereka (peserta didik) ke dalam dunia kita (guru), dan antarkan dunia kita (guru) ke dalam dunia mereka (peserta didik), (2) proses pembelajaran bagaikan orkestra simfoni, dan (3) pembelajaran harus berdampak terhadap pembentukan kompetensi yang dapat diamati dan dipraktikkan.

Pembelajaran konvensional merupakan pembelajaran yang selama ini sering digunakan guru dalam proses pembelajaran. Pembelajaran ini adalah salah satu model pembelajaran yang bepusat pada guru. Menurut Sanjaya (2006:259) "Pada pembelajaran konvensional siswa ditempatkan sebagai obyek belajar yang berperan sebagai penerima informasi secara pasif. Jadi pada umumnya penyampaian pelajaran menggunakan metode ceramah, tanya jawab dan penugasan". Berdasarkan paparan penjelasan di atas, adapun model konvensional yang digunakan pada kelas kontrol yaitu metode ceramah.

Menurut Sagala (2010:201) bahwa "Metode ceramah adalah sebuah bentuk interaksi melalui penerangan dan penuturan lisan dari guru kepada siswa.
Metode ceramah sesuai digunakan untuk menyampaikan informasi kepada siswa". Adapun metode ceramah menggunakan cara belajar dengan penuturan untuk memberi informasi atau pembelajaran yang disampaikan pada peserta didik. Menurut Sagala (2010:202) langkahlangkah metode ceramah dijelaskan sebagai berikut: (a) melakukan pendahuluan, (b) menyajikan materi dengan memperhatikan faktor-faktor, dan (c) menutup pelajaran pada akhir pelajaran.

Penelitian terdahulu yang relevan dengan penelitian ini antara lain sebagi berikut. Penelitian yang dilakukan oleh Mustika Sari dalam skripsinya yang berjudul "Penerapan Model Quantum Learning untuk Meningkatkan Kualitas Pembelajaran Materi Energi Panas dan Bunyi Siswa Kelas IV Sekolah Dasar Negeri Randugutnting 4 Kota Tegal”. Kedua, Brian Leon Karlos pada tahun 2012 yang berjudul "Peningkatan Kemampuan Menulis Puisi Siswa Kelas $X$ Sma Kristen 1 Magelang dengan Menggunakan Metode Quantum Learning”. Ketiga, Kiki Indah Pratiwi pada tahun 2014 yang berjudul "Keefektifan Model Quantum Learning terhadap Minat dan Hasil Belajar Bangun Datar Pada siswa Kelas V Sekolah Dasar Negeri Tunon 2 Kota Tegal”. Keempat, Samrotul Ilmi dalam skripsinya yang berjudul "Efektivitas Penerapan Model Pembelajaran Quantum Learning Terhadap Motivasi dan Hasil Belajar Kimia Siswa Kelas X Semester 2 Di MAN Wonokromo Pleret Bantul Yogyakarta".

Adapun kerangka berpikir dalam penelitian ini dijelaskan sebagai berikut. 


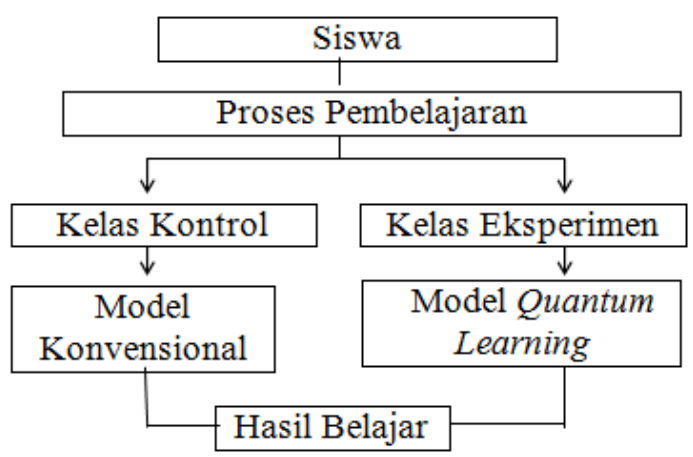

Bagan I. Kerangka Pemikiran

Asumsi merupakan anggapan penulis dalam melakukan penelitian. Menurut Arikunto (2010:65) "Anggapan dasar (Asumsi) adalah suatu hal yang diyakini kebenarannya oleh peneliti dan harus dirumuskan secara jelas". Di dalam penelitian ini penulis berasumsi sebagai berikut: (1) penggunaan model quantum learning akan mempengaruhi keterampilan menulis puisi siswa kelas $\mathrm{X}$ Akuntansi 2 SMK Negeri 2 Kota Jambi Tahun Ajaran 2018/2019, (2) hasil belajar akan meningkat setelah diberikan perlakuan yakni model quantum learning.

Hipotesis dapat diartikan sebagai dugaan sementara, atau kemungkinan jawaban dari sebuah penelitian. Menurut Sugiyono (2015:96) "Hipotesis merupakan jawaban sementara terhadap rumusan masalah penelitian, dimana rumusan masalah penelitian telah dinyatakan dalam bentuk pertanyaan". Rumusan hipotesis penelitian ini sebagai berikut.

$\mathrm{H}_{0}$ : Model quantum learning tidak berpengaruh terhadap hasil Pembelajaran keterampilan menulis puisi siswa kelas X Akuntansi SMK Negeri 2 Kota Jambi pada tahun ajaran 2018/2019.

$\mathrm{H}_{\mathrm{a}}: \begin{gathered}\text { Model } \\ \text { berpengaruh }\end{gathered} \begin{gathered}\text { quantum } \\ \text { terhadap }\end{gathered} \quad \begin{array}{r}\text { learning } \\ \text { hasil }\end{array}$
Pembelajaran keterampilan menulis puisi siswa kelas X Akuntansi SMK Negeri 2 Kota Jambi pada tahun ajaran 2018/2019.

\section{METODE PENELITIAN}

Penelitian ini menggunakan metode penelitian quasi eksperiment atau eksperimen semu, menurut Sukardi (2013:16) "Penelitian kuasi eksperimen dapat diartikan sebagai penelitian yang mendekati eksperimen atau eksperimen semu". Sedangkan menurut Arikunto (2010:207) "Penelitian quasi eksperiment merupakan penelitian yang tidak memenuhi seluruh persyaratan yang ditetapkan dalam penelitian murni”. Adapun menurut Sugiyono (2015:114) "Quasi eksperiment digunakan karena pada kenyataannya sulit mendapatkan kelompok kontrol yang digunakan untuk penelitian". Penggunaan metode quasi eksperiment ini didasarkan atas pertimbangan yang sesuai dengan tujuan penelitian untuk memperoleh deskripsi secara objektif dalam pembelajaran keterampilan menulis puisi. Pendekatan yang digunakan dalam penelitian ini adalah pendekatan kuantitatif.

Tempat penelitian ini dilakukan di Kota Jambi, yaitu di SMK Negeri 2 Kota Jambi Tahun Ajaran 2018/2019. Lokasi sekolah berada di jalan Gelatik Pasir Putih, Kec. Jambi Selatan, Kota Jambi.

Populasi merupakan keseluruhan subjek penelitian. Menurut Darmadi (2013:50) "Populasi adalah keseluruhan objek penelitian yang berfungsi sebagai sumber data dalam penelitian". Tujuan penggunaan populasi dalam setiap penelitian agar dapat ditentukan besarnya anggota sampel yang diambil dari anggota populasi. Populasi penelitian ini adalah seluruh kelas X Akuntansi SMK Negeri 2 Kota Jambi Tahun Ajaran

Pengaruh Model Quantum Learning terhadap Keterampilan Menulis Puisi Siswa Kelas X Akuntansi SMK Negeri 2 Kota Jambi 
2018/2019. Jumlah populasi seluruhnya ada 106 siswa.

Sampel merupakan bagian dari populasi. Menurut Darmadi (2013:50) "Sampel adalah sebagian dari populasi yang dijadikan Objek/subjek penelitian". Cara pengambilan sampel dapat dilakukan dengan teknik purposive sampling. Menurut Triyono (2013:152) "purposive sampling adalah cara dalam memilih anggota sampel dilandasi pertimbangan-pertimbangan tertentu dengan tujuan-tujuan tertentu pula". Teknik purposive sampling digunakan karena kelas X Akuntansi SMK Negeri 2 Kota Jambi pada mata pelajaran Bahasa Indonesia diajarkan oleh guru yang sama. kelas akuntansi 2 dipilih sebagai kelas eksperimen yang diajarkan dengan model quantum learning, dan kelas kontrol yaitu kelas akuntansi 3 yang diajarkan dengan menggunakan cara pembelajaran langsung

Terdapat dua variabel dalam penelitian ini, yaitu: Variabel bebas independent variable dan variable terikat dependent variable. Menurut Darmadi (2013:19) "Variabel bebas adalah variabel yang menjadi sebab munculnya variabel terikat". Variabel bebas (X) dalam penelitian ini adalah model pembelajaran quantum learning. Selanjutnya menurut Darmadi (2013:19) "Variabel terikat merupakan variabel yang dipengaruhi atau variabel yang menjadi akibat karena adanya variabel bebas". Variabel terikat (Y) adalah keterampilan puisi siswa kelas X SMK Negeri 2 Kota Jambi.

Teknik pengumpulan data merupakan cara strategis yang digunakan oleh seorang peneliti untuk mengumpulkan data dalam penelitian. Teknik pengumpulan data dalam penelitian ini berupa tes tertulis.
Instrumen penelitian merupakan alat yang digunakan penulis untuk mendapatkan data. Dalam penelitian ini instrumen yang digunakan berupa tes. Tes unjuk kerja diberikan kepada subjek penelitian yaitu kelas eksperimen dan kelas kontrol.

Analisis data dalam penelitian ini bertujuan untuk menguji kebenaran hipotesis yang diajukan. Data yang dianalisis adalah skor hasil penugasan akhir siswa. Sebelum analisis dilakukan terlebih dahulu uji normalitas dan uji homogenitas.

Uji normalitas dilakukan untuk mengetahui apakah data yang didapat dari masing-masing variabel berdistribusi normal. Uji normalitas menggunakan rumus Chi-Kuadrat (Chi square). Adapun prosedur pengujiannya adalah sebagai berikut:

1. Menentukan Hipotesis

$\mathrm{H}_{0}=$ data sampel berasal dari populasi berdistribusi normal

$\mathrm{H}_{\mathrm{a}}=$ data sampel berasal dari populasi tidak berdistribusi normal menentukan rata-rata

2. Menentukan rata-rata

3. Menentukan standar deviasi

4. Cari $X^{2}$ hitung dengan rumus :

Keterangan:

$$
X^{2}=\sum\left[\frac{\left(F_{0-F_{h}}\right) 2}{F_{h}}\right]
$$

$X^{2}=$ harga Chi-Kuadrad yang dicari

$F_{0}=$ frekuensi yang ada

$F_{h}=$ frekuensi yang diharapkan (Arikunto, 2010:312)

5. Cari $X_{\text {tabel }}$ dengan derajat kebebasan $(\mathrm{dk})=$ banyaknya kelas $(\mathrm{k})-3$ dan taraf kepercayaan $95 \%$ atau signifikan $=5 \%$

6. Kriteria pengujian:

Jika $X_{\text {hitung }}^{2}<X^{2}$ tabel $\mathrm{H}_{0}$ diterima dan $\mathrm{H}_{\mathrm{a}}$ ditolak 
Jika $X^{2}{ }_{\text {hitung }}>X^{2}{ }_{\text {tabel }} \mathrm{H}_{\mathrm{a}}$ diterima dan $\mathrm{H}_{0}$ ditolak

Uji homogenitas dilakukan untuk mengetahui apakah sampel diambil dari populasi yang berasal dari derivasi yang sama dan tidak menunjukan perbedaan yang signifikasikan. Rumus yang digunakan adalah sebagai berikut.

$$
F=\frac{s_{t}^{2}}{s_{c}^{2}}
$$

Keterangan :

$s^{2}{ }_{t}=$ variansi kelompok eksperimen

$s_{c}^{2}=$ variansi kelompok kontrol (Sudjana, 2005:249)

Tes yang digunakan untuk Uji $F$ yaitu dengan membandingkan variasi terbesar dan variasi terkecil. Syarat agar variasi bersifat homogen apabila $F_{\text {hitung }}$ lebih kecil dari pada $F_{\text {tabel }}$ pada taraf signifikasi $\mathrm{a}=0.05$.

Permasalahan penelitian yang ada akan diuji dengan melakukan serangkaian penguji hipotesis dengan taraf signitifikasi $a^{=} 0,05$. Untuk menganalisis hasil eksperimen yang menggunakan post-test one group desain. Maka rumus yang digunakan adalah sebagai berikut:

$$
=\frac{t_{\text {hitung }}}{\sqrt{\left\{\frac{(n-1) S_{1}^{2}+\left(n_{2}-1\right) S_{2}^{2}}{n_{1}+n_{2}-2}\right\}\left(\frac{1}{n_{1}}+\frac{1}{n_{2}}\right)}}
$$

Keterangan :

$\bar{x}_{1} \quad=$ Mean kelas eksperimen

$\bar{x}_{2} \quad=$ Mean kelas kontrol

$S_{1}^{2}=$ Standart deviasi kelas eksperimen

$S_{2}^{2} \quad=$ Standart deviasi kelas kontrol

$n_{1} \quad=$ Jumlah siswa kelas eksperimen

$n_{2} \quad=$ Jumlah siswa kelas kontrol (Sugiyono, 2015:273).
Hasil perhitungan data dengan rumus uji-t tersebut kemudian dicocokkan dengan harga dalam $t_{\text {tabel }}$ pada taraf signifikasikan $\alpha=0,05$ jika

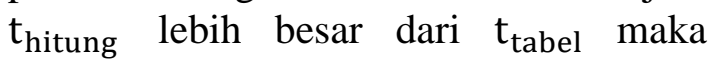
diasumsikan $\mathrm{H}_{\mathrm{a}}$ diterima. Demikian sebaliknya, jika $t_{\text {hitung }}$ lebih kecil dari $\mathrm{t}_{\text {tabel }}$ maka $\mathrm{H}_{\mathrm{a}}$ ditolak.

\section{HASIL DAN PEMBAHASAN}

Penelitian ini dilaksanakan di SMK Negeri 2 Kota Jambi tahun ajaran 2018/2019. Kelas X Akuntansi 2 sebagai kelas eksperimen yang berjumlah 35 orang diajarkan menggunakan model quantum learning dan kelas X Akuntansi 3 sebagai kelas kontrol berjumlah 35 orang diajarkan menggunakan model konvensional. Pada kelas eksperimen nilai tertinggi 100 dan nilai terendah 65 selanjutnya siswa pada kelas kontrol nilai tertinggi 95 dan nilai terendah 50. Nilai rata-rata yang diperoleh kelas eksperimen yaitu 80,42 lebih tinggi dibandingkan nilai rata-rata pada kelas kontrol yaitu 74 . Nilai simpangan baku kelas eksperimen 12,088 lebih kecil dari pada simpangan baku kelas kontrol 13,922.

Uji normalitas digunakan untuk mengetahui apakah data yang didapat dari masing-masing sampel berdistribusi normal. Pengujian normalitas dilakukan dengan bantuan SPSS 2.0 diketahui bahwa nilai signifikan kelas eksperimen adalah 0,170 yang berarti lebih besar taraf nyata 0,05 hal ini menunjukkan bahwa kelas eksperimen berdistribusi normal dan diketahui bahwa nilai signifikasi kelas kontrol adalah 0,178 yang berarti lebih besar dari taraf nyata 0,05 berdistribusi normal.

Uji homogenitas digunakan untuk mengetahui apakah data yang didapat dari masing-masing sampel homogen. Pengujian homogenitas dilakukan dengan

Pengaruh Model Quantum Learning terhadap Keterampilan Menulis Puisi Siswa Kelas X Akuntansi SMK Negeri 2 Kota Jambi 
bantuan SPSS 20 diketahui bahwa nilai signifikan adalah 0,462 yang berarti lebih besar taraf nyata 0,05 hal ini menunjukkan bahwa kelas eksperimen dan kelas kontrol memiliki variansi yang homogen.

Uji hipotesis dalam penelitian ini menggunakan uji $t$ dua sampel independent untuk membandingkan ratarata dari kelas tidak berhubungan satu sama lainnya. Uji $t$ dua sampel independent dapat dilihat bahwa sig $\mathrm{f}$ hitung $0.135>0,05$, ini berarti kedua sampel homogen. Berdasarkan pada $\mathrm{f}$ hitung mempunyai keputusan perbedaan yang sama diasumsikan maka hipotesis secara statistik diperoleh nilai sig t hitung $0,043<0,05$ yang berarti $\mathrm{H}_{0}$ ditolak dan $\mathrm{H}_{\mathrm{a}}$ diterima artinya pembelajaran keterampilan menulis puisi yang diajarkan menggunakan model quantum learning lebih baik dibandingkan pembelajaran keterampilan menulis puisi yang diajarkan menggunakan model konvensional.

Berdasarkan analisis data hasil belajar siswa terhadap pembelajaran keterampilan menulis puisi, kelas eksperimen yang diajarkan menggunakan model quantum learning diperoleh nilai rata-rata 80,42. Hasil belajar peserta didik terhadap pembelajaran keterampilan menulis puisi, kelas kontrol yang diajarkan menggunakan model konvensional diperoleh nilai rata-rata 74 . Hal ini menunjukkan bahwa rata-rata pembelajaran keterampilan menulis puisi yang diajarkan menggunakan model quantum learning lebih tinggi dari pada rata-rata pembelajaran keterampilan menulis puisi dengan menggunakan model konvensional.

\section{SIMPULAN}

Berdasarkan hasil analisis data,
dapat disimpulkan bahwa pembelajaran keterampilan menulis puisi pada kelas X Akuntansi 2 sebagai kelas eksperimen yang diajarkan menggunakan model quantum learning memperoleh nilai rata-rata 80,42 dan simpangan baku 12,088 dan pembelajaran keterampilan menulis puisi kelas $\mathrm{X}$ Akuntansi 3 sebagai kelas kontrol yang diajarkan dengan menggunakan model pembelajaran konvensional memperoleh nilai rata-rata 74 dan simpangan baku 13,922. Berdasarkan uji hipotesis menggunakan uji $t$ dua sampel independent diperoleh sig t hitung 0,043 $<$ 0,05. Dimana $\mathrm{H}_{0}$ ditolak dan $\mathrm{H}_{\mathrm{a}}$ diterima. Jadi dapat disimpulkan pembelajaran keterampilan menulis puisi yang diajarkan menggunakan model quantum learning lebih baik dibandingkan pembelajaran keterampilan menulis puisi dengan menggunakan model pembelajaran konvensional. Dengan demikian dapat disimpulkan bahwa model quantum learning berpengaruh secara signifikan terhadap keteramilan menulis puisi siswa kela $\mathrm{x}$ akuntansi 2 SMK Negeri 2 Kota Jambi.

\section{DAFTAR PUSTAKA}

Abdurrahman, Alwiyah. (2016). Quantum Learning. Bandung: Kaifa Arikunto, Suharsimi. (2010). Prosedur Penelitian Suatu Pendidikan Praktik. Jakarta: Rineka Cipta.

Dalman. (2014). Keterampilan Menulis. Jakarta: PT. Raja Grapindo Persada.

Damayanti, D. (2013). Buku Pintar Sastra Indonesia Puisi, Sajak, Syair, Pantun, dan Majas. Yogyakarta: Araska.

Pengaruh Model Quantum Learning terhadap Keterampilan Menulis Puisi Siswa Kelas X Akuntansi SMK Negeri 2 Kota Jambi 
Darmadi, Hamid. (2013). Dimensidimensi Metode Penelitian Pendidkan dan sosial. Bandung: Alfabeta.

Daryanto. (2009). Panduan Proses Pembelajaran Kreatif dan Inovatif. Jakarta:

Buku yang Cerdas Mencerdaskan.

Gustaviana, R., Rahima, A., \& Sujoko, S. (2018). Pengaruh Penggunaan Model Kepala Bernomor terhadap Keterampilan Menulis Teks Pidato Siswa Kelas IX G SMP Negeri 2 Kota Jambi Tahun Ajaran 2017/2018. Jurnal Ilmiah Dikdaya, 8 (1), 187-194.

Hamalik, Oemar. (2007). Psikologi Belajar dan Mengajar. Bandung: Sinar Baru Algensindo.

Istiqomah, dkk. (2017). Bahasa Indonesia SMA/MA/SMK/MAK Kelas $\quad X . \quad$ Jakarta: Kemendikbud.

Kosasih, E. (2008). Apresiasi Sastra Indonesia. Jakarta: PT: Persa.

Markazi,

El. (2016).

https://www.elmarkazi.com/lang

kah-langkah-menulis-puisi/ 2019. diakses tanggal 4 Februari

Mulyasa. 2014. Guru dalam Implementasi Kurikulum 2013. Bandung: PT. Remaja Rosdakarya.

Puspita, Tara. Gafar, Abdoel. Rofii, Afif. (2019). Pengaruh Penggunaan Model Pembelajaran Think Pair Share terhadap Keterampilan Menulis Surat Pribadi Siswa Kelas VII SMP Negeri 5 Kota Jambi. Aksara: Jurnal Ilmiah Pendidikan Bahasa dan Sastra Indonesia Vol. 3 No. 1 April 2019. http://aksara.unbari.ac.id/index.p hp/aksara/article/viewFile/104/5 9

Rofii, Afif., Fathiaty, Murtadho., Rahmat, Aceng. (2019 A). Needs Analysis: A Learning Model for CTL-Based Academic Writing. Proceedings of the Eleventh Conference on Applied Linguistics (conaplin 2018) https://www.atlantispress.com/procedings/conaplin$18 / 125911424$

Rofii, Afif., Murtadho, Fathiaty., Rahmat, Aceng. (2019 B). The Perception of Lecturers and Students on Learning Model of Contextual-Based Academic Writing. Proceeding First International Conference on Advances in Education, Humanities, and Language. Malang: EAI (https://eudl.eu/doi.418/eai.23-32019.2284915

Rofii, A., Murtadho, F., Rahmat, A. (2019 C) "The Effectiveness of Contextual-Based Academic Writing Learning Model. Asian ELF Journal.Volume 23. Issue $6.3 \quad$ November 2019. https://www.asian-efljournal.com/main-journals/2019main-journal/volume-23-issue-63-november-2019/

Sanjaya, Wina. (2006). Strategi Pembelajaran Berorientasi Standar Proses Pendidikan. Jakarta: Kencana Prenada Media Group.

Sudjana. (2005). Metoda Statiska. Bandung: Tarsito.

Sugiyono. (2015). Metode Penelitian Pendidikan, Bandung: Alfabeta.

Pengaruh Model Quantum Learning terhadap Keterampilan Menulis Puisi Siswa Kelas X Akuntansi SMK Negeri 2 Kota Jambi 
Syaiful Sagala. (2010). Konsep dan Makna Pembelajaran. Bandung:

Alfabeta

Tarigan, Hendry Guntur. (1984). Menulis

Sebagai Suatu Keterampilan

Berbahasa. Bandung:

Angkasa.

Trianto. (2007). Model Pembelajaran

Terpadu dalam Teori dan

Praktek. Jakarta: PT.

Prestasi Pustaka.

Triyanto, dkk. (2013). Terampil berbahasa Indonesia.

Yogyakarta: CV. Andi

Offset.

Triyono. (2013). Metodologi Penelitian Pendidikan. Yogyakarta: Ombak

Wahyuni, Nur Esa dan Baharuddin. (2010). Teori Belajar dan Pembelajaran. Jogjakarta: ARRuzz Media.

Yanti, Nirma, Gafar, Abdoel. Rofii, Afif. (2018). Pengaruh Penggunaan

Media Gambar terhadap Kemampuan Menulis Puisi Rakyat Siswa Kelas VII SMP Negeri 6 Kota Jambi Tahun Ajaran 2017/2018. Aksara: Jurnal Ilmiah Pendidikan Bahasa dan Sastra Indonesia Vol. 2 No. 2 September 2018.

Pengaruh Model Quantum Learning terhadap Keterampilan Menulis Puisi Siswa Kelas X Akuntansi SMK Negeri 2 Kota Jambi 